\title{
Education programs designed to support the optics/photonics industry
}

\section{Leno Pedrotti, Darrell Hull, Arthur Guenther}

Leno S. Pedrotti, Darrell M. Hull, Arthur H. Guenther, "Education programs designed to support the optics/photonics industry," Proc. SPIE 3190, Fifth International Topical Meeting on Education and Training in Optics, (8 December 1997); doi: 10.1117/12.294406

Event: Fifth International Topical Meeting on Education and Training in Optics, 1997, Delft, Netherlands 
Educational Programs Designed to Support the Optics/Photonics Industry

Leno S. Pedrotti, Darrell M. Hull, Arthur H. Guenther ${ }^{\dagger}$

Center for Occupational Research and Development

P.O. Box 216809, Waco, Texas, 76702-1689

\begin{abstract}
The explosive photonics industry in the United States and elsewhere signals a critical need for comprehensive programs in education for the preparation of photonics technicians, engineers, and scientists. This paper outlines curricular plans in photonics education which begin at the $9^{\text {th }}$ grade in high school and end generally at the $14^{\text {th }}$ grade with an associate of applied science degree. Beginning with comprehensive lists of appropriate tasks for photonics technicians - as identified by photonics-related industriesextrapolation is made to specific courses, sequences of courses, and on to comprehensive high school/ postsecondary curricula, with appropriate emphasis on the necessary basics in mathematics, science communications, and introductory technology courses. The identification of a photonics core for technician education is a major part of this paper. In addition, a strategy for the development of the photonics core courses in modular form - with the desired pedagogical organization of a typical module -is discussed.
\end{abstract}

Keywords: photonics, technician education, six-year programs, photonics core, course modules

\title{
1. INTRODUCTION
}

There are many indications that the photonics industry in the United States continues to grow rapidly and steadily. The Optoelectronics Industry Development Association (OIDA) expects the U.S. photonics industry to double in size every four years-growing to a $\$ 500$ billion market by the year 2013. ${ }^{1}$ Informed forecasters predict that "photonics is the foremost emerging technology that will affect all manufacturing industries over the next few decades, surpassing the combined impact of the transistor and the microprocessor." And the editors of Photonics Spectra, in their "1997 Global Photonics Market Forecast" report "... in most cases, the photonics industry does have a window into the world, but often it does not open wide enough." ${ }^{3}$ In other words, the potential for further growth and expansion remains as promising as ever.

With the dynamic growth of any industry there comes always a parallel need for qualified technicians, engineers, and scientists - to fill the jobs, meet production schedules, and move the technology still further ahead. While programs dedicated to the education and training of Laser/Electro-Optics Technicians (LEOT) were developed by the Center for Occupational Research and Development (CORD) ${ }^{4}$ in the 1970s and sustained through the 1980s and early 1990s, it is clear that the photonics industry of today requires technicians with a broader, more comprehensive education than that provided by the past two-year postsecondary programs. A new two-year curriculum is needed to merge optical science with laser technology and electronics, and give increased attention to such topics as fiber optics, miniaturized sensors and detectors, laser diodes, modulators and other recent innovations surfacing in the photonics industry of today.

In the design of a photonics technician education program, beginning in high school and leading to an associate of applied science degree at two-year postsecondary institutions, it is necessary to begin with an input from the photonics industry. It should come as no surprise that both industry and the educational community look for the same characteristics in the graduates of our schools. Educators seek to prepare students who perform well on their first job and can apply their broad education to the new challenges which, inevitably, arise as their careers advance. Industry seeks entry-level technicians who will "hit-theground-running" and then be able to adapt to the many new tasks that arise as the technology matures and

\footnotetext{
${ }^{\dagger}$ Currently at the University of New Mexico, Albuquerque, New Mexico.
} 
the industry grows. Thus industry representatives and educators are working together more frequently today to design programs that lead to a "good education" and also meet the current and future needs for an educated workforce.

In the balance of this paper, which focuses on the design of a six-year photonics technician-education program, we will address the following issues:

- Based on industry input, what are the hand skills and head skills required of an entry-level photonics technicians?

- How do we move from detailed knowledge of these skills to seamless high school/postsecondary educational programs that deliver both types of skills-with due attention paid to foundation courses in mathematics, science, and communication?

- What are the core photonics courses required in a six-year photonics technician-education program?

- What are the advantages of modular course materials for core photonics courses?

- What are the characteristics of modular course materials?

\section{INPUT FROM INDUSTRY}

Photonics - generally regarded as a technology involved in the generation, manipulation, transport, detection and use of radiant energy - is a main thrust of many opto-electronic industries which deal with communications, transportation, manufacturing, information highways, national defense, health, public safety, entertainment, environmental control, monitoring, imaging, display, and space exploration. In the two-year period 1993/1994 - with an enabling grant from the U.S. Department of Education-CORD worked with representatives of these diverse industries, each of which employed photonics technicians, to identify and catalog the many hand and head skills required of such technicians. This effort culminated in a comprehensive set of photonics skill standards ${ }^{5}$ which listed both basic knowledge skills and on-the-job performance skills. Examples of these head and hand skills follow:

- Samples of typical mathematics skills required are:

- Use mathematical logic and reasoning to extrapolate from special problems to more general situations.

- Learn about mathematical patterns and functions.

- Learn how to use scientific calculators, estimate and round numbers

- Learn about perimeters and areas of rectangles, triangles, parallelograms, trapezoids, and circles

- Learn about surface areas and volumes of boxes, cones, cylinders, and spheres

- Use ratio and proportion to make and read scale drawings, and to make generalizations

- Learn about precision, accuracy and tolerance in measurement

- Learn about roots and powers

- Solve linear and nonlinear equations for a specified variable

- Learn how to draw and interpret graphs

- Use metal tapes, vernier calipers, micrometer calipers, for example, to measure linear dimensions

- Samples of typical science-based skills include:

- Apply the scientific method in planning a solution to a problem.

- Make scientific inquiry a habit in solving laboratory problems.

- Learn about relationships between distance, speed, acceleration, and time in linear and angular motion

- Learn about pressure and flow rates in fluid systems 
- Measure energy, power and efficiency of mechanical, fluid, electrical and thermal devices

- Learn how to measure flow rate, pressure, temperature, force, voltage, current and resistance with appropriate instruments.

- Learn how to use a dual-trace oscilloscope to troubleshoot circuits and to measure voltage and frequency

- Learn how to assemble equipment from schematic or pictorial diagrams

- Use appropriate transducers to measure mechanical, fluid, electrical and thermal signals

- Learn how to assemble lenses, mirrors, prisms, sources and detectors in optical systems

- Use ray-tracing methods to locate images in two- and three-lens systems

- Typical examples of on-the-job performance skills are:

- Given general instructions for a laboratory task or measurement, identify the needed equipment and assemble correctly to complete the task or obtain the data.

- Operate, maintain, align and troubleshoot Nd:YAG lasers

- Clean, maintain, align, mount, install, and operate spectroscopic instruments in laser-optical systems

- Troubleshoot, repair, maintain, and use electronic power supplies in laser systems

- Install, align, clean, maintain and operate A-O modulators and Q-switches in laser systems

The sample mathematics and science skills are indicative of those knowledge skills derived from foundation courses in geometry, algebra, physics, and so on. The on-the-job performance skills are much more specific and indicate the type and breadth of tasks expected of a photonics technician in the workplace.

With this initial input from industry on required knowledge and performance skills-and industry's continual involvement during the development of the high school/postsecondary six-year curriculum (denoted as $4+2$ for the 4 years in high school and 2 years in a postsecondary college)-educators in charge of curriculum design can then move ahead to lay out the required curriculum.

\section{DESIGNING A 4+2 CURRICULUM}

An overview of the "flow process" from industry-defined skills to course identification and curriculum design is shown in Figure $1 .{ }^{6}$ With the task lists in hand, foundation courses such as algebra, geometry, statistics, chemistry, and physics are selected. In each of these basic courses, the presentation is made "contextual," with an appropriate balance of abstract and concrete concepts, and with an appropriate mixture of head and hand skills in practical laboratory settings. Following this, the core courses which form the technical heart of a photonics technician education program are identified and spelled out in sufficient detail to enable experienced, competent authors to prepare the text and laboratory materials for use in the classroom. And, in keeping with the good practice found in most two-year postsecondary schools which prepare technicians, appropriate specialty areas in, for example, health, industrial machining, and fiber optic communications are developed and offered as part of the program. 

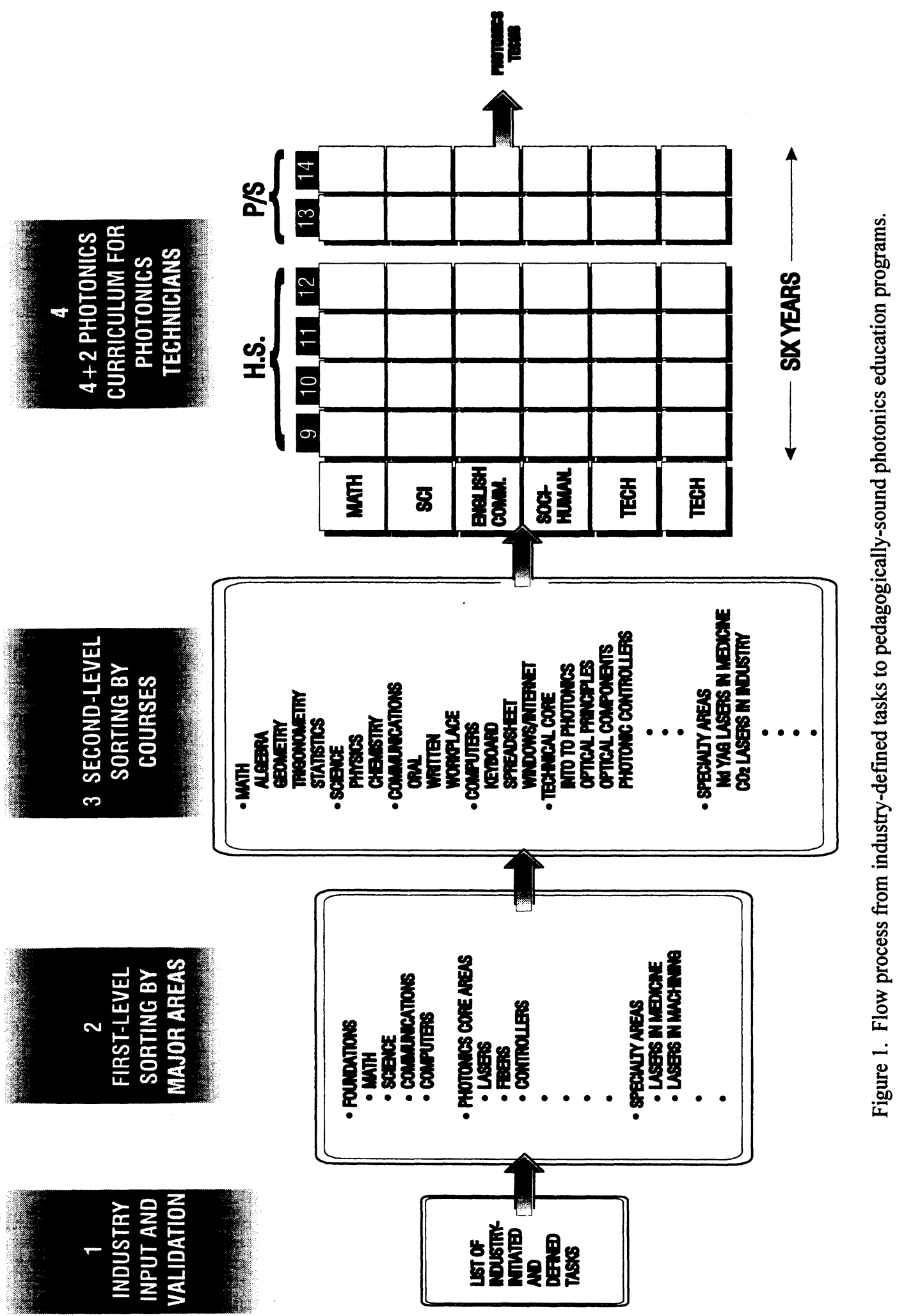
The six-year program shown in box format at the right side of Figure 1 contains the four-year high school part and the two-year continuation at the 13/14 postsecondary level. Figure 2, below, fills in a few more details, suggesting appropriate mathematics, science and technology courses at the high-school level and several courses at the 13/14 year level. The three-course sequence in Applied Mathematics covers the essentials of algebra, geometry, some trigonometry and statistics with considerable hands-on experience involving measurement in mathematics laboratories. The courses in applied chemistry and applied physics pull together theoretical concepts and laboratory-based, hands-on applications which serve to reinforce directly the head/hand skills needed by technicians in the workplace. In the 13/14 year, a block of time is reserved for concentration on the all-important photonics core courses. We address this important element next.

\begin{tabular}{|c|c|c|c|c|c|c|c|c|}
\hline & $\begin{array}{c}9^{m} \\
\text { Grade }\end{array}$ & $\begin{array}{l}10^{\mathrm{m}} \\
\text { Grade }\end{array}$ & $\begin{array}{l}11^{\mathrm{th}} \\
\text { Grade }\end{array}$ & $\begin{array}{c}12^{\text {th }} \\
\text { Grade }\end{array}$ & Freshm & $\tan$ Year & Sophon & nore Year \\
\hline Math & $\begin{array}{l}\text { Applied } \\
\text { Math } 1\end{array}$ & $\begin{array}{l}\text { Applied } \\
\text { Math } 2\end{array}$ & $\begin{array}{l}\text { Applied } \\
\text { Math } 3\end{array}$ & Algebra 2 & Statistics & $\begin{array}{l}\text { Precalculus } \\
\text { or Calculus } \\
\text { a }\end{array}$ & & $\begin{array}{l}1 \\
1 \\
1 \\
1 \\
1 \\
1 \\
1\end{array}$ \\
\hline Science & $\begin{array}{l}\text { Applied } \\
\text { Chemistry }\end{array}$ & $\begin{array}{l}\text { Applied } \\
\text { Physics } 1\end{array}$ & $\begin{array}{l}\text { Applied } \\
\text { Physics } 2\end{array}$ & & & $\begin{array}{l}y_{1} \\
\vdots \\
1 \\
1 \\
1\end{array}$ & & $\begin{array}{l}1 \\
1 \\
1 \\
1 \\
1 \\
1\end{array}$ \\
\hline $\begin{array}{l}\text { English } \\
\text { and } \\
\text { Social } \\
\text { Science }\end{array}$ & \multicolumn{4}{|c|}{$\begin{array}{l}\text { English I, II, and III } \\
\text { Geography, History, and Government } \\
\text { Applied Communications }\end{array}$} & $\begin{array}{l}\text { Interpersonal } \\
\text { Communi- } \\
\text { cations }\end{array}$ & $\begin{array}{l}\text { Composi- } \\
\text { tion } \\
\text { an }\end{array}$ & $\begin{array}{l}\text { Economics } \\
\text { for } \\
\text { Technology }\end{array}$ & $\begin{array}{l}\text { Technical } \\
\text { Writing } \\
\\
\end{array}$ \\
\hline \multirow{2}{*}{$\begin{array}{l}\text { Photonics } \\
\text { Techno- } \\
\text { logy }\end{array}$} & & & Electronics & $\begin{array}{l}\text { Digital } \\
\text { Circuits \& } \\
\text { Micro- } \\
\text { processors }\end{array}$ & \multirow{2}{*}{\multicolumn{4}{|c|}{$\begin{array}{c}\text { Eight Photonics } \\
\text { Core Courses }\end{array}$}} \\
\hline & & & $\begin{array}{l}\text { Machining } \\
\text { Materials } \\
\text { Processing }\end{array}$ & $\begin{array}{l}\text { Computer } \\
\text { Applica- } \\
\text { tions } \\
\text { Software }\end{array}$ & & & & \\
\hline
\end{tabular}

Figure 2. A suggested six-year curriculum leading to an AAS degree for photonics technicians.

\section{PHOTONICS CORE COURSES}

As mentioned earlier, the heart of a photonics technician education program lies in the photonics core courses. These are the courses which build on the mathematics and science foundations in the six-year program and which prepare the photonics technician for specific employment in any of the many diverse photonics industries. These are the courses which include both head skills and hand skills and which enable the technician to use the wide array of optoelectronics equipment commonly found in photonics industries.

Based on the interaction with industry representatives and experienced teachers of laser technicians, we have identified eight courses as a photonics core, each course made up of a certain set of modules. (A module is similar to a chapter in a traditional textbook, but prepared to stand alone as a separate "book.") The eight core courses we have singled out are:

1. Fundamentals of Photonics Technology ( 8 modules) 
2. Lasers and Other Light Sources ( 9 modules)

3. Photonics Applications I (8 modules)

4. Optics and Optical Components (7 modules)

5. Detection and Measurement ( 9 modules)

6. Fiber Optics and Communications (8 modules)

7. Imaging and Display ( 9 modules)

8. Photonics Applications II (8 modules)

The details for the 8 modules proposed for Course 1, Fundamentals of Photonics Technology, are given, as a sample, in Figure 3. Here we indicate the classroom concepts to be covered in each module along with proposed (or potential) laboratory projects to be completed. (Similar breakdowns exist for the remaining seven core courses.)

\begin{tabular}{|c|c|c|c|}
\hline \multicolumn{2}{|r|}{$\begin{array}{c}\text { MODULE } \\
\text { DESCRIPTION }\end{array}$} & $\begin{array}{l}\text { CLASSROOM } \\
\text { CONCEPTS }\end{array}$ & \multirow{2}{*}{$\begin{array}{l}\text { POTENTIAL LABORATORY } \\
\text { PROJECTS } \\
\text { - Show Spectrum of Several Light } \\
\text { Sources } \\
\text { - Identify Principal Lines } \\
\end{array}$} \\
\hline 1.0 & $\begin{array}{l}\text { Nature and } \\
\text { Properties of Light }\end{array}$ & $\begin{array}{ll}\text { - Oscillating EM Fields } & \text { - Electromagnetic Spectrum } \\
\text { - Wavelength, Frequency } & \text { - Blackbody Radiation } \\
\text { - Velocity of Light } & \text { - Particle, Ray, Wave Concepts }\end{array}$ & \\
\hline 2.0 & $\begin{array}{l}\text { Light Sources, } \\
\text { Lasers, and Laser } \\
\text { Safety }\end{array}$ & $\begin{array}{l}\text { - Non-Laser Light Sources } \\
\text { - Fluorescent, Incandescent, } \\
\text { LED, Gas Discharge, etc. } \\
\text { - Operation of a Helium-Neon } \\
\text { Laser }\end{array}$ & $\begin{array}{l}\text { - Operation of HeNe Laser } \\
\text { - Laser Safety Procedures } \\
\text { - Measure Beam Divergence Angle } \\
\text { - Measure Laser Spot Size }\end{array}$ \\
\hline & Basic Optics & $\begin{array}{l}\text { - Geometric Optics (reflection, refraction, etc.) } \\
\text { - Physical Optics (interference, diffraction, etc.) } \\
\text { - Basic Optical Components (lenses, mirrors, etc.) }\end{array}$ & $\begin{array}{l}\text { - Snell's Law } \\
\text { - Total Internal Reflection } \\
\text { - Young's Two-slit Interference } \\
\text { Pattern }\end{array}$ \\
\hline 4.0 & $\begin{array}{l}\text { Optical Detectors } \\
\text { and Human Vision }\end{array}$ & $\begin{array}{l}\text { - Basic Optical Detectors (Photon and Thermal Detectors) } \\
\text { - Principles of Detection (Photoelectric, Photoconductive, etc.) } \\
\text { - Common Circuits for Detectors, Power and Energy Meters } \\
\text { - Optics of the Eye and Human Vision }\end{array}$ & $\begin{array}{l}\text { - Use Power Meter to Measure HeNe } \\
\text { Laser } \\
\text { - Setup and Operate Circuit for Silicon } \\
\text { PIN Photodiode, Measure Chopped } \\
\text { HeNe Laser Light }\end{array}$ \\
\hline 5.0 & $\begin{array}{l}\text { Optical Wave- } \\
\text { guides and Fibers }\end{array}$ & $\begin{array}{l}\text { - Fiber Loss } \\
\text { - Medical Applications of Fibers } \\
\text { - Fiber Sensors }\end{array}$ & $\begin{array}{l}\text { - Coupling Light Into a Fiber } \\
\text { - Measuring Coupling Loss, } \\
\text { Attenuation } \\
\text { - Demonstrate Stress Effects (Loss, } \\
\text { Polarization Changes) }\end{array}$ \\
\hline 6.0 & $\begin{array}{l}\text { Basics of Fiber } \\
\text { Optic Tele } \\
\text { communications }\end{array}$ & $\begin{array}{l}\text { - Basic Principles } \\
\text { - Components (Cables, Connectors, Transmitters, Receivers) } \\
\text { - Tradeoffs in Component Choices } \\
\text { - Capabilities of Installed Systems } \\
\end{array}$ & $\begin{array}{l}\text { - Build and Operate a Fiber Optic } \\
\text { Telecommunications Link }\end{array}$ \\
\hline 7.0 & $\begin{array}{l}\text { Basic Principles } \\
\text { and Applications } \\
\text { of Holography }\end{array}$ & $\begin{array}{l}\text { - Fundamentals of Holographic Recording } \\
\text { - Reconstruction Methods } \\
\text { - Preservation of Phase Information } \\
\text { - Applications (Display, Security, Bar Code Scanning, etc.) }\end{array}$ & $\begin{array}{l}\text { - Record and Reconstruct Holograms } \\
\text { of Simple Objects Using a HeNe } \\
\text { Laser }\end{array}$ \\
\hline 8.0 & $\begin{array}{l}\text { Photonic Devices } \\
\text { for Imaging and } \\
\text { Display }\end{array}$ & $\begin{array}{l}\text { - Imaging } \\
\text { - CCD Cameras, Vidicons, Image Intensifiers } \\
\text { - Display } \\
\text { - CRTs, TFT and LCD Flat Panels, Electroluminescent }\end{array}$ & $\begin{array}{l}\text { - Image Capture at Varying Light } \\
\text { Levels } \\
\text { - Measurement of Display Resolution, } \\
\text { Brightness }\end{array}$ \\
\hline
\end{tabular}

Figure 3. Details of eight modules which make up Course 1, Fundamentals of Photonics Technology

Each of the eight modules described in Figure 3 are "fleshed out" in a three-level outline of expanded detail. An author assigned to prepare the final, complete, classroom-ready module uses the three-level outline (approved by a "technical" committee) as a comprehensive guide from which to develop the final text for each module. 


\section{THE USE OF MODULAR FORMATS}

Considerable experience with educational materials prepared in the late 1970s for the preparation of laser/electro-optics technicians and used for the past 20 years has convinced CORD of the value of modular materials. When prepared in modular format, the collection of separate modules enables instructors to take advantage of:

- flexible selection and packaging of appropriate photonics concepts

- adaptation of the selected modules for special sequences

- appropriate clustering of selected modules for development of minor fields of concentration in related disciplines such as electronics, mechanical engineering, medicine, and so on.

The typical structure of a course module generally follows the outline given below:

- Compact description and purpose of the module, presented at the very beginning

- List of prerequisites to alert students (and teachers) when the modules are regrouped and used out of "ordinary" sequence

- List of learning and competency objectives

- A hands-on laboratory up front, before discussion begins, to motivate the learner

- A description of typical work scenarios for technicians in the photonics industry

- Core text material, conceptually developed, with theory and practice brought together

- Hands-on laboratories designed around industry-standard photonics equipment

- Problem-solving on relevant photonics problems typical of those encountered in the workplace

The modular development process for the eight photonics core courses identified earlier, encompassing some 66 separate modules, is perceived to progress as follows:

- Initial drafts are prepared by experienced teachers who use the 3-level outlines prepared by a photonics technical committee as guides for the desired text material

- Drafts are reviewed and changes recommended by a technical committee, industry personnel, photonics specialists, and educators

- Final modules are prepared and field-tested with experienced faculty in existing laser/electro-optics postsecondary schools

- Currency/adaptations/innovations/instructor feedback of developed core courses is managed through a curriculum "morphing" process

The morphing process referred to above makes use of current computer "wizardry" which brings together teaching faculty via electronic E-mail and World Wide Web pages, in a real-time updating of an existing curriculum. The ideas surrounding a curriculum morphing process are described in detail in a companion paper "Subjecting Optics and Photonics Text Materials to a Morphing Process."7

\section{A FINAL COMMENT}

The focus of this paper has been on the necessary cooperation between industry and education in order to develop a photonics technician education program. Such a program has been shown to require four years in high school and two years in a postsecondary school, terminating generally with an associate of applied science degree in photonics. Clearly, since progression up the educational ladder should always be a viable option for students enrolled in a two-year postsecondary program, considerable thought has been given to articulation on to four-year bachelor of science programs. Thus, programs which begin at the $9^{\text {th }}$ grade in high school and extend through the $4^{\text {th }}$ year of college are referred to as $4+2+2$ programs, with various exit points. The essential features of a $4+2+2$ progression are shown in Figure 4 . 


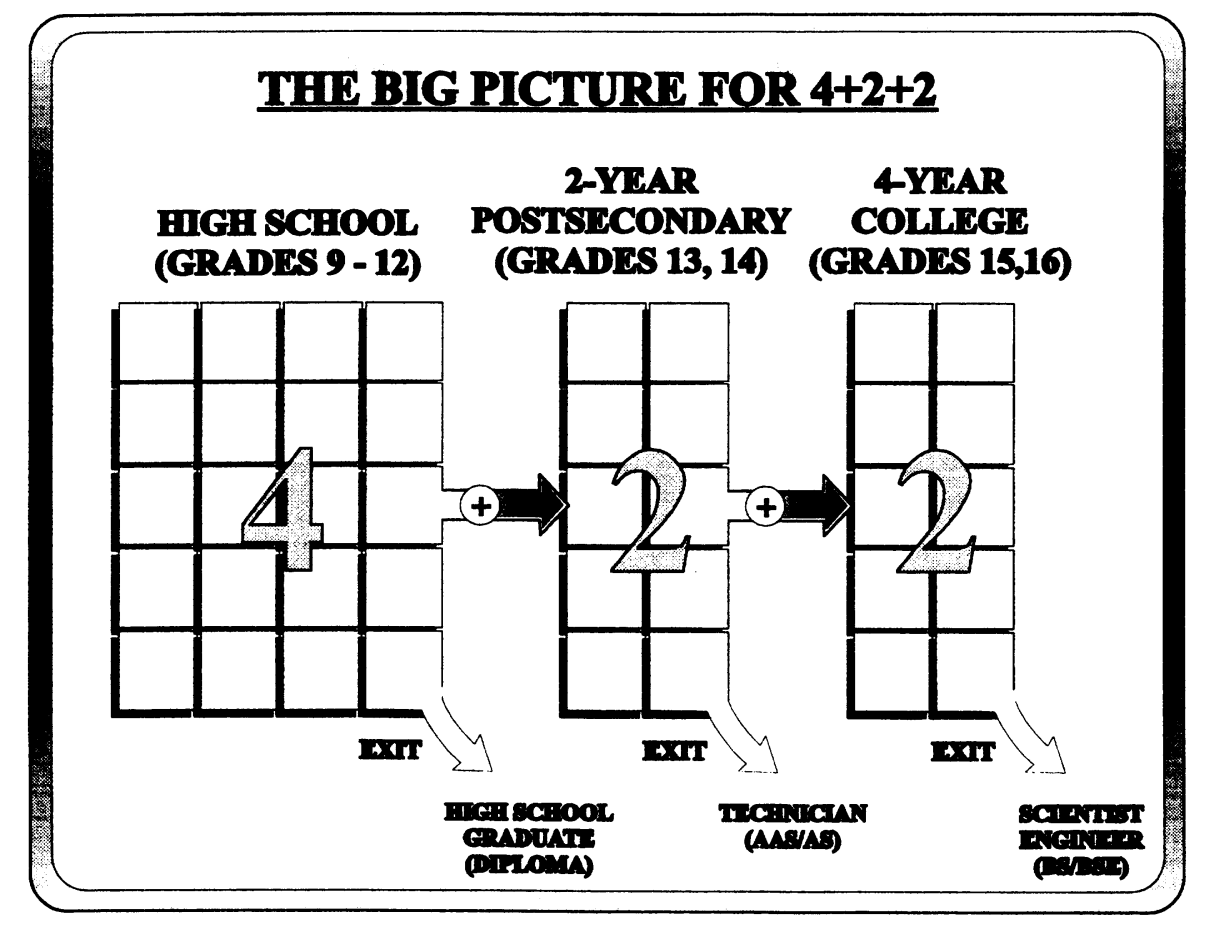

Figure 4. A general $4+2+2$ plan for preparing a photonics workforce.

As discussed in a previous paper, articulation from a two-year postsecondary program on to a fouryear college program can proceed via a BS degree in Engineering Technology (BSET), a BS degree in Electrical Engineering (BSEE), or a BS degree in Optical Engineering. The transition however, as explained in the referenced paper, may require an extra year of course work, primarily to strengthen the theoretical science and mathematics concepts upon which four-year programs are generally built. In any case, those students who begin with an AAS degree in mind, as a photonics technician, and then move on to complete a BS degree, even with the additional year required, will find a ready market in industry for their dual package of valuable hands-on, laboratory-oriented skills and firm theoretical foundations.

\footnotetext{
${ }^{1}$ Optoelectronics Technology Roadmap: Conclusions and Recommendations," Optoelectronics Industry Development Association, 1995.

${ }^{2}$ Angelo DePalma. "Photonics: The Technology and its Potential." Fort Lee, NJ: Technical Insights, Inc., 1994, as quoted in "Photonics Will Surpass the Transistor," Optics and Photonics News, 1994.

3 "The 1997 Global Photonics Market," Photonics Spectra, August 1997, Laurin Publishing Company, Inc. Pittsfield, Massachusetts.

${ }^{4} \mathrm{CORD}$ is a nonprofit, public service organization-located in Waco, Texas-which helps educators in schools and industries across the country address the technical education, training, and retraining needs of the workforce.

${ }^{5}$ Troy, Charles T. "Standards Issued for Photonics Technicians, Photonics Spectra, April 1995, Laurin Publishing Company, Inc., Pittsfield, Massachusetts. (The complete set of skill standards, entitled National Photonics Skill Standards for Technicians, (1995), is available from CORD.)

${ }^{6}$ L.S. Pedrotti, N. Massa, E.P. Soulsby, J. Enderle, and C.S. Roychoudhuri. "Comprehensive Approach to Photonics Education for Technicians, Engineers, and Scientists in 4+2+2 Programs. SPIE 1995 International Conference in Education in Optics, San Diego, CA.

${ }^{7}$ D.M. Hull, A.H. Guenther, and L.S. Pedrotti, "Subjecting Optics and Photonics Text Materials to a Morphing Process." (Presented at the SPIE Fifth International Topical Meeting on Education and Training in Optics, Delft, The Netherlands, paper CP-5, August 19, 1997.
} 